\title{
Implementasi Model Pembelajaran Kooperatif Tipe Numbered Head Together (NHT) Dalam Meningkatkan Kemampuan Berpikir Kritis Siswa Pada Pembelajaran IPS
}

\author{
Fitri Ayu Febrianti \\ SDN 6 Cangkuang \\ fitriayufebrianti5@gmail.com
}

\begin{abstract}
The low of critical thinking skill of students became a crucial problem in social studies learning. Therefore, to stimulated this skill, used the Numbered Head Together (NHT) model. The problem of the research "is there an effect of cooperative learning model type NHT toward student's critical thinking skill in social studies?". The purpose of the research was to knew the effect of cooperative learning model type NHT toward student's critical thinking skill in social studies. The research method was quasi-experiments, and took the students of grade $V$ SDN Tanjungsari as population. The sample used a saturated sampling technique, so there were two classes which were sampled, VA class which consist 20 students, and VB class which consist 20 students. VA class as a control class and got a conventional model with media based image. Meanwhile, the VB class as an experimental class and used NHT model. The research instruments used a test (multiple choice and explained), and observation. Based on the results of the statistic analysis, $t_{\text {value }}=2,89$, and table $=$ 2,025 , or $t_{\text {value }}>t_{\text {table. }}$ The conclusion presented there was significant effect of $\mathrm{NHT}$ model to student's critical thinking skill in social studies.
\end{abstract}

Keyword: critical thinking skill, cooperative learning model type NHT

\begin{abstract}
ABSTRAK
Rendahnya kemampuan berpikir kritis siswa menjadi masalah krusial dalam pembelajaran IPS. Oleh karena itu, perlu adanya upaya agar pembelajaran IPS dapat menstimulus siswa untuk berpikir kritis, salah satunya dengan menggunakan model pembelajaran kooperatif tipe Numbered Head Together (NHT). Adapun rumusan masalah dari penelitian ini, “apakah terdapat pengaruh model pembelajaran kooperatif tipe $N H T$ terhadap kemampuan berpikir kritis siswa pada mata pelajaran IPS?". Sementara itu,tujuan penelitian ini untuk mengetahui pengaruh model pembelajaran kooperatif tipe $N H T$ terhadap kemampuan berpikir kritis siswa pada mata pelajaran IPS. Metode penelitian yang digunakan adalah kuasi eksperimen dengan populasi terbatas yaitu siswa kelas V SDN Tanjungsari. Sampel dipilih dengan menggunakan teknik sampling jenuh, sehingga terdapat dua kelas yang dijadikan sebagai sampel, yaitu kelas VA yang berjumlah 20 orang dan VB yang berjumlah 20 orang. Kelas VA dijadikan sebagai kelas kontrol, dan mendapat model pembelajaran konvensional berbasis media gambar. Sementara itu, kelas VB dijadikan sebagai kelas eksperimen, dan mendapat model pembelajaran kooperatif tipe $N H T$. Instrumen penelitian yang digunakan berupa tes (pilihan ganda dan uraian), serta lembar observasi. Berdasarkan hasil analisis secara statistik, diperoleh hasil $t_{\text {hitung }}$ sebesar 2,89 dan $\boldsymbol{t}_{\text {tabel }}$ dengan taraf signifikansi 5\% $(a=0,05)$ sebesar 2,025. Dari hasil tersebut, maka dapat dinotasikan $t_{\text {hitung }}>t_{\text {tabel }}$, sehingga dapat disimpulkan bahwa terdapat pengaruh model pembelajaran kooperatif tipe $N H T$ terhadap kemampuan berpikir kritis siswa pada mata pelajaran IPS.
\end{abstract}

Kata Kunci: kemampuan berpikir kritis, model pembelajaran kooperatif tipe $\mathrm{NHT}$

\section{PENDAHULUAN}

Dewasa ini, kemampuan berpikir kritis menjadi keterampilan yang sangat esensial dalam pendidikan.Kemampuan ini seyogianya dikembangkan sejak usia dini agar siswa memiliki keterampilan intelektual tingkat tinggi. Pentingnya kemampuan berpikir kritis juga diungkapkan oleh Peter (dalam Indira dkk., 2017, hlm. 61), "Student who are able to think critically are able to solve problem effectively". Dengan kata lain, siswa yang memiliki kemampuan berpikir kritis, ia mampu menyelesaikan masalah secara efektif. 
Digitalisasi Pendidikan mengharuskan siswa diarahkan pada kemampuan literacy yang tinggi dengan mengembangkan kemampuan berpikir kritisnya. Tetep \& Suparman (2019) menjelaskan "Technical skills, critical understanding and communicative abilities are competencies that can be used for the formation of someone's individual and social". Bahwa era digital kemampuan kritis dan literasi media menjadi kemampuan yang harus disiapkan dalam pembelajaran di sekolah oleh guru. Kemampuan berfikir dan literasi siswa dalam proses pembelajaran saat ini masih cenderung rendah. Dalam ruang lingkup makro, kemampuan berpikir kritis masih menjadi permasalahan pendidikan nasional. Hal ini dibuktikan dengan hasil Programme for International Student Assessment atau PISA (dalam Novita, 2018) yang diselenggarakan pada tahun 2015. Merujuk pada hasil PISA tersebut, Indonesia masih berada pada peringkat 10 besar terbawah, dengan rata-rata skor 395. Adapun soal yang diujikan didominasi oleh soal yang berorientasi pada Higher Order Thinking Skill (HOTS) atau kemampuan berpikir tingkat tinggi. Hal ini merepresentasikan bahwa kemampuan siswa dalam menjawab soal yang mengacu pada kemampuan berpikir kritis dan analitis masih cenderung rendah.

Tidak hanya menjadi problematik dalam ruang lingkup makro, permasalahan berpikir kritis siswa juga terjadi di cakupan mikro seperti SDN Tanjungsari. Rendahnya kemampuan ini dapat ditinjau dari proses dan hasil belajar siswa pada mata pelajaran Ilmu Pengetahuan Sosial (IPS). Idealnya, pendidikan IPS mampu menjembatani siswa untuk mengembangkan kemampuan berpikir kritisnya (Permendiknas Nomor 22 Tahun 2006). Namun kenyataannya bertolak belakang, pendidikan IPS belum mampu mengakomodasi kemampuan ini. Berdasarkan penelitian pendahuluan di SD tersebut, ketuntasan belajar siswa pada tes UTS mata pelajaran IPS hanya mencapai 25\%. Hal ini menginterpretasikan bahwa mayoritas siswa belum mampu memahami konsep dasar tentang materi IPS, sehingga kemampuan berpikir kritis siswa cenderung rendah.

Rendahnya kemampuan berpikir kritis juga didukung oleh hasil wawancara dengan guru kelas V SDN Tanjungsari. Berdasarkan hasil wawancara, pembelajaran IPS di kelas masih berorientasi pada hafalan. Hafalan yang dimaksud seperti mengingat tanggal-tanggal dan nama para tokoh pada suatu kejadian penting, tanpa memaknai maksud dari kejadian tersebut. Hal ini menyebabkan siswa hanya sebatas tahu tanpa berpikir lebih lanjut mengenai fenomena tersebut.

Sementara itu, berdasarkan hasil observasi terhadap kegiatan pembelajaran, kemampuan berpikir kritis siswa dalam mata pelajaran IPS cenderung rendah. Hal ini terlihat selama proses pembelajaran, peran guru lebih mendominasi dibandingkan siswa. Begitupun pada sesi tanya jawab, pertanyaan yang diajukan hanya sebatas pertanyaan pengetahuan yang jawabannya bersifat teoretis. Dampaknya, dalam menjawab soal uraian, siswa cenderung memberikan jawaban singkat dan tidak mendalam. Fenomena ini bertentangan dengan pendapat Gokhale (dalam Solihah, 2019), bahwa soal berpikir kritis merupakan soal yang berorientasi pada kegiatan analisis, sintesis, dan evaluasi dari suatu konsep.

Ada banyak faktor pemicu masalah ini, salah satunya model pembelajaran yang digunakan di kelas tersebut, yaitu model pembelajaran konvensional yang berorientasi pada teacher center. Model pembelajaran konvensional dilandasi oleh teori belajar behavioristik. Teori behavioristik menekankan bahwa perubahan perilaku siswa terjadi jika mendapatkan stimulus. Model pembelajaran konvensional dianggap kurang menstimulus siswa untuk berpikir kritis dalam proses pembelajaran, sebab hanya berpusat pada peran guru. Model pembelajaran konvensional hanya menuntut siswa pada kekuatan hafalan, tanpa mengembangkan cakrawala berpikir, sehingga siswa sulit belajar lebih kritis (Susanto, 2014). 
Menyikapi masalah tersebut, maka diperlukan sebuah model pembelajaran yang lebih memberdayakan siswa untuk mengembangkan kemampuan berpikir kritisnya. Salah satu model yang dapat digunakan ialah model pembelajaran kooperatif tipe Numbered Head Together (NHT) yang dikembangkan oleh Russ Frank pada tahun 1992 (Nizar dan Suherman, 2016). Model pembelajaran kooperatif tipe $N H T$ ini dilatarbelakangi oleh aliran filsafat konstruktivisme yang dikemukakan oleh G.Vico dari Italia (Susanto, 2014). Berdasarkan pembelajaran konstruktivistik, belajar merupakan sebuah proses aktif, tentang membantu siswa mengonstruksi makna mereka sendiri, bukan tentang jawaban yang benar tanpa benarbenar memahami konsepnya.

Mengingat inovatifnya model NHT terhadap kemampuan berpikir kritis siswa, maka terdapat beberapa penelitian yang relevan mengenai keberhasilan model pembelajaran ini. Seperti penelitian Kawuwung (2014, hlm. 17) yang menegaskan bahwa "Strategi pembelajaran kooperatif $N H T$ memberikan kontribusi yang lebih baik bagi peningkatan kemampuan berpikir kritis siswa dibandingkan model konvensional dengan metode ceramah".

Berdasarkan pemaparan di atas, model pembelajaran kooperatif tipe $N H T$ sudah teruji lebih efektif dibandingkan dengan model pembelajaran konvensional berbasis metode ceramah. Dengan demikian, peneliti hendak melakukan sentuhan inovatif dalam penelitian eksperimen ini, yaitu dengan daya pembanding model konvensional berbasis media gambar. Hal ini dikarenakan media gambar dapat membantu siswa meningkatkan kemampuan berpikirnya dan mengubah peran guru ke arah yang lebih positif dan produktif (Afriyanti, dkk, 2012). Selain itu, menurut Yuswanti (2018) , media gambar diharapkan dapat menyampaikan materi menjadi lebih jelas dan lebih mudah dicerna dibandingkan dengan penjelasan guru secara lisan.

Sejauh ini belum ada penelitian serupa yang dilakukan, terutama di tingkat sekolah dasar, sehingga peneliti melaksanakan penelitian dengan mengusung judul "Implementasi Model Pembelajaran Kooperatif Tipe Numbered Head Together (NHT) dalam meningkatkan Kemampuan Berpikir Kritis Siswa pada Pembelajaran IPS". Penelitian ini merupakan penelitian eksperimen yang dilakukan di kelas V SDN Tanjungsari tahun pelajaran 2018/2019. Adapun Rumusan Masalah Penelitianya sebagai berikut : (1) Bagaimana penerapan model pembelajaran kooperatif tipe $N H T$ di kelas V SDN Tanjungsari pada mata pelajaran IPS?, (2) Bagaimana kemampuan berpikir kritis siswa yang mendapat model pembelajaran kooperatif tipe NHT pada mata pelajaran IPS?, (3) Apakah terdapat pengaruh model pembelajaran kooperatif tipe $N H T$ terhadap kemampuan berpikir kritis siswa kelas $\mathrm{V}$ SDN Tanjungsari pada mata pelajaran IPS?

\section{KAJIAN PUSTAKA}

\section{Model Pembelajaran Kooperatif Tipe Numbered Head Together (NHT)}

Menurut Kagan (dalam Susanto, 2014, hlm. 226), "NHT adalah suatu tipe model pembelajaran kooperatif yang merupakan struktur sederhana dan terdiri atas empat tahap yang digunakan untuk me-review faktafakta dan informasi dasar yang berfungsi untuk mengatur interaksi siswa". Sedangkan Hamdani (2011) mendefinisikan model pembelajaran NHT sebagai model belajar dengan cara memberi nomor pada siswa, kemudian secara random, guru memanggil nomor siswa.

Dari pendapat di atas, maka dapat disimpulkan bahwa model $N H T$ adalah suatu model pembelajaran berkelompok, yang didalamnya terdapat siswa bernomor variatif, agar dapat bertanggung jawab pada tugas kelompoknya. 
Tujuan model pembelajaran $N H T$ ialah memberikan kesempatan kepada siswa untuk saling berbagi gagasan dan mempertimbangkan jawaban yang paling tepat (Huda, 2013).

Prosedur implementasi model pembelajaran NHT terdiri dari fase dikemas dalam sintak Kagan ( dalam Susanto, 2014) seperti di bawah ini.

a. Langkah 1 Penomoran

(Numbering), dengan prosedur:

1) guru membagi para siswa menjadi beberapa kelompok dan memberi mereka nomor, sehingga tiap siswa dalam tim memiliki nomor yang berbeda;

2) menginformasikan materi yang akan dibahas;

3) mengomunikasikan tujuan pembelajaran;

4) memotivasi siswa agar timbul rasa ingin tahu tentang konsepkonsep yang akan dipelajari.

b. Langkah 2 Pengajuan Pertanyaan (Questioning), dengan prosedur:

1) menjelaskan materi secara sederhana;

2) mengajukan pertanyaan variatif kepada siswa;

c. Langkah 3 Berpikir Bersama (Head Together), dengan prosedur:

1) siswa memikirkan pertanyaan yang diajukan oleh guru;

2) para siswa berpikir bersama untuk meyakinkan bahwa tiap orang mengetahui jawaban tersebut.

d. Langkah 4 Pemberian Jawaban

(Answering), dengan prosedur:

1) guru memanggil suatu nomor dari salah satu kelompok secara acak;

2) siswa dari tiap kelompok dengan nomor yang sama mengangkat tangan;

3) siswa menyiapkan jawaban untuk seluruh kelas, ditanggapi oleh kelompok lain;

4) jika jawaban dari hasil diskusi kelas sudah dianggap betul, siswa diberi kesempatan untuk mencatat, dan apabila jawaban masih salah, guru akan mengarahkan;

5) guru memberikan pujian kepada siswa atau kelompok yang menjawab betul.

Ulya, dkk. (2017, hlm. 2063) mengemukakan kelebihan model NHT diantaranya "setiap siswa menjadi siap belajar, siswa dapat melakukan diskusi dengan sungguh-sungguh, dan siswa yang pandai dapat mengajari yang kurang pandai". Sementara itu, kekurangan model NHT (dalam Ulya, dkk., 2017) ialah kemungkinan nomor yang sudah dipanggil dapat dipanggil kembali oleh guru, dan tidak semua anggota kelompok yang memiliki nomor yang sama terpanggil oleh guru untuk presentasi mewakili kelompoknya.

\section{Kemampuan Berpikir Kritis}

Johnson (2010), menyatakan bahwa berpikir kritis merupakan proses sistematis yang digunakan dalam aktivitas mental seperti pemecahan masalah, pembuat keputusan, menganalisis asumsiasumsi, dan penemuan secara ilmiah. Selain itu, menurut Ennis ( dalam Mulyana, 2008), berpikir kritis merupakan cara berpikir secara beralasan dan reflektif dengan menekankan pada pembuatan keputusan tentang apa yang harus dipercayai atau dilakukan. 
Berdasarkan paradigma di atas, maka dapat ditarik konklusi bahwa kemampuan berpikir kritis ialah kecakapan individu untuk menyelesaikan sebuah problematik secara sistematis, logis, dan analitis. Menurut Sapriya (2017, hlm. 87), tujuan berpikir kritis ialah "untuk

menguji suatu pendapat atau ide, termasuk di dalamnya melakukan pertimbangan atau pemikiran yang didasarkan pada pendapat yang diajukan".

Ennis (dalam Nio dkk, 2017, hlm. 58) mengemukakan bahwa terdapat lima kelompok besar yang menaungi indikator berpikir kritis, yaitu "basic clarification, the bases for the decision, inference, advanced clarification, supposition and integration".

\section{METODE PENELITIAN}

Berdasarkan metodenya, penelitian yang dilakukan peneliti ialah penelitian eksperimen. Penelitian ini bertujuan untuk melihat pengaruh model pembelajaran kooperatif tipe $N H T$ terhadap kemampuan berpikir kritis siswa. Untuk melihat pengaruh, maka diperlukan dua kelompok yang terdiri dari kelompok eksperimen, dan kelompok kontrol. Metode yang digunakan ialah Quasi Experiments. Adapun desain penelitian Quasi Experiments yang digunakan adalah Non-equivalent Control Group Design. Menurut Sugiyono (2018, hlm. 79), "desain ini hampir sama dengan pretest-posttest control group design, hanya pada desain ini kelompok eksperimen maupun kelas kontrol tidak dipilih secara random". Adapun desain ini disajikan dalam tabel 1.

\section{Tabel 1}

\section{Non-equivalent Control Group Design}

\begin{tabular}{|c|c|c|}
\hline O1 & $\mathrm{X}$ & $\mathrm{O} 2$ \\
\hline $\mathrm{O} 3$ & - & $\mathrm{O} 4$ \\
\hline
\end{tabular}

Keterangan :

$\mathrm{X}=$ Kelas eksperimen

- $\quad=$ Kelas kontrol

$\mathrm{O}_{1} \quad=$ Pretest kelas eksperimen

$\mathrm{O}_{2} \quad=$ Posttest kelas eksperimen

$\mathrm{O}_{3} \quad=$ Pretest kelas kontrol

O4 = Posttest kelas kontrol

Penelitian dilakukan di SDN Tanjungsari, yang berlokasi di Kampung Tanjungsari, RT 02/RW 04, Desa Tanjungsari, Kecamatan Karangpawitan, Kabupaten Garut, Provinsi Jawa Barat.

Populasi yang digunakan dalam penelitian ini ialah populasi homogen, yaitu populasi yang unsur-unsurnya memiliki sifat yang sama, dan populasi terbatas, yaitu populasi yang memiliki batas kuantitatif karena karakteristik yang terbatas (Margono, 2004). Berdasarkan ketentuan tersebut, maka siswa kelas V SDN Tanjungsari yang berjumlah 40 orang dijadikan populasi, dengan pertimbangan tertentu.

Sementara itu, sampel dalam penelitian ini ialah siswa kelas VA dan VB SDN Tanjungsari yang masingmasing terdiri dari 20 orang siswa. Teknik pengambilan sampel yang digunakan ialah teknik sampling jenuh. Sampling jenuh merupakan teknik untuk menentukkan sampel bila semua anggota populasi digunakan sebagai sampel (Sugiyono, 2018). Di sisi lain, menurut Arikunto (2012, hlm. 104), “jika populasinya kurang 
dari 100 orang, maka jumlah sampelnya diambil secara keseluruhan, tetapi jika populasinya lebih besar dari 100 orang, maka bisa diambil $10-15 \%$ atau 20-25\% dari jumlah populasinya". Berdasarkan

paradigma tersebut, sampling jenuh dipilih karena jumlah populasinya tidak lebih dari 100 orang, sehingga seluruh siswa kelas V SDN

Tanjungsari dijadikan sebagai sampel.

Pada penelitian ini, cara yang digunakan peneliti untuk mengumpulkan data, ialah teknik tes dan non tes. Tes yang digunakan berupa soal multiple choice yang berjumlah 15 butir dan uraian yang berjumlah 5 butir. Sementara itu, teknik non tes yang digunakan ialah observasi, wawancara, dan dokumentasi.

\section{HASIL PENELITIAN DAN PEMBAHASAN}

Penelitian ini dilakukan terhadap dua kelompok sampel yang saling bebas atau dua sampel dengan subjek berbeda. Kedua kelompok subjek ini diberi perlakuan yang berbeda pula. Kelas eksperimen mendapat model pembelajaran kooperatif tipe $N H T$, sedangkan kelas kontrol mendapat model pembelajaran konvensional berbasis media gambar.

Rata-rata hasil pretest kelas eksperimen ialah 40,10, sedangkan rata-rata hasil pretest kelas kontrol ialah 44,25, sehingga selisih hasil pretest kedua kelas ialah 4,15.

Sementara itu, rata-rata hasil posttest kelas eksperimen ialah 76,80 , sedangkan rata-rata hasil posttest kelas kontrol ialah 72,20, sehingga selisih hasil posttest kedua kelas ialah 4,6.

Selanjutnya, data pretest dan posttes dari kedua kelas dianalisis untuk mengetahui hasil penelitian berupa penerimaan atau penolakan hipotesis. Uji hipotesis yang digunakan ialah uji t.

Berdasarkan hasil perhitungan data pretest, diperoleh $\mathrm{t}_{\text {hitung }}$ sebesar $-1,44$. Sedangkan, $\mathrm{t}_{\text {tabel }}$ dengan taraf signifikansi $5 \%(\mathrm{a}=0,05)$ diketahui sebesar 2,025. Kriteria pengujian hipotesis: jika -t tabel $\leq_{t} \quad \leq_{\text {hitung t } t a b e l}$ maka Ho diterima. Karena $t_{\text {hitung }}=-1,44$ dan t tabel $=2,025$, maka thitung < t tabel sehingga Ho diterima.

Sementara itu, hasil perhitungan data posttest menunjukkan $\mathrm{t}_{\text {hitung }}$ sebesar 2,89 dan $\mathrm{t}_{\text {tabel }}$ sebesar 2,025. Karena $t_{\text {hitung }}=2,89$ dan $\mathrm{t}_{\text {tabel }}=2,025$, maka $\mathrm{t}_{\text {hitung }}>\mathrm{t}_{\text {tabel }}$ sehingga Ho ditolak dan Ha diterima. Dengan kata lain, terdapat pengaruh model pembelajaran kooperatif tipe Numbered Head Together (NHT) terhadap kemampuan berpikir kritis siswa kelas V SDN Tanjungsari pada mata pelajaran IPS.

Selain analisis data kuantitatif, dalam penelitian ini dilakukan pula analisis data kualitatif berupa hasil observasi. Berdasarkan hasil pengamatan yang dilakukan, keterlaksanaan pembelajaran oleh guru pada treatment pertama ialah 78 atau termasuk kategori baik. Sementara itu, untuk treatment kedua, performa guru mencapai 90 atau termasuk kategori sangat baik.

Sementara itu, jumlah siswa yang aktif di kelas eksperimen pada treatment pertama sebanyak 11 orang. Sedangkan persentase siswa aktif secara klasikal ialah 55\% atau termasuk kategori cukup aktif. Sementara itu, pada treatment kedua, jumlah siswa yang aktif mencapai 15 orang, sedangkan persentase siswa aktif secara klasikal ialah $75 \%$ atau termasuk kategori aktif.

\section{Implementasi Model $\mathbf{N H T}$}

Model NHT dilatarbelakangi oleh aliran filsafat konstruktivisme yang dikemukakan oleh G.Vico ( Susanto, 2014). Berdasarkan pembelajaran konstruktivistik, belajar merupakan sebuah proses aktif, siswa mengonstruksi pengetahuan sendiri. Model NHT dipilih sebab 
mengajarkan tentang bekerja sama dengan kelompok, hingga bertanggung jawab dalam kesetaraan dalam rangka mencapai tujuan pembelajaran

( Suparmi, 2012).

Merujuk pada esensi model pembelajaran NHT tersebut, siswa dituntut untuk bekerja sama dalam kelompok yang heterogen. Secara tidak langsung, hal ini bisa menjembatani siswa untuk berpikir lebih kritis, sebab siswa dihadapkan pada pemikiran "beragam". Perbedaan persepsi membuat siswa berpikir lebih mendalam mengenai suatu hal dari berbagai sudut pandang.

Penggunaan model NHT pada mata pelajaran IPS merupakan pemilihan yang tepat, sebab model pembelajaran ini meliputi langkah pembelajaran yang sistematis dan relevan dengan tujuan pendidikan IPS. Adapun prosedur implementasi dari model $N H T$, diadaptasi dari sintak Kagan (dalam Susanto, 2014), dimulai dari penomoran (numbering), pengajuan pertanyaan (questioning), berpikir bersama (heads together), dan pemberian jawaban (answering).

Untuk pertemuan pertama di kelas eksperimen yang menggunakan model $N H T$, kegiatan pembelajaran berlangsung dengan cukup baik. Keterlaksanaan pembelajaran oleh guru pada treatment pertama mencapai 78 atau termasuk kategori baik. Sedangkan keaktifan siswa secara klasikal 55\% atau termasuk kategori cukup aktif. Mayoritas siswa mulai menikmati alur pembelajaran dan terstimulus begitu baik. Namun pada awal pembelajaran, beberapa siswa masih pasif dalam mengemukakan pendapat atau mengajukan pertanyaan mengenai materi yang dipelajari. Kendala lain di awal pembelajaran, beberapa siswa perlu beradaptasi dengan kelompok heterogennya yang notabene terbentuk secara random. Meskipun demikian, kendala tersebut tidak menjadi masalah krusial yang mengganggu keberlangsungan proses penelitian.

Pada treatment kedua, kegiatan pembelajaran berlangsung lebih baik dibandingkan dengan treatment sebelumnya. Siswa lebih aktif untuk mengemukakan pendapat dan berdiskusi. Hal ini ditunjang oleh hasil observasi siswa yang menunjukkan persentase keaktifan siswa mencapai $75 \%$ atau termasuk kategori aktif. Begitupun dengan performa guru yang mencapai 90 atau termasuk kategori sangat baik.

Model NHT yang dilakukan di kelas eksperimen pada konsep "Proklamasi Kemerdekaan Indonesia"

terlihat bahwa siswa dapat mengekspresikan diri bersama kelompoknya. Model ini dilaksanakan dalam bentuk kelompok yang heterogen dengan mengombinasikan keunggulan pembelajaran kooperatif dan individual. Adanya kombinasi ini, siswa menjadi lebih tertarik mengikuti pembelajaran. Pasalnya, model ini dapat membantu siswa menyelesaikan masalah secara bersama dan menumbuhkan sikap mandiri saat nomornya dipanggil untuk menjawab pertanyaan yang diajukan.

Berdasarkan pemaparan tersebut, maka dapat ditarik konklusi bahwa implementasi model NHT di kelas V SDN Tanjungsari berjalan dengan baik. Hal ini terlihat dari persentase keaktifan siswa secara klasikal yang tergolong aktif, performa guru yang baik, dan prosedur implementasi model NHT yang dilaksanakan secara sistematis.

\section{Kemampuan Berpikir Kritis Siswa yang Mendapat Model $\mathbf{N H T}$}

Dalam kegiatan pembelajaran IPS mengenai konsep proklamasi kemerdekaan Indonesia, mayoritas siswa yang mendapat model NHT cenderung aktif dan responsif terhadap "stimulus" yang diberikan guru. Pada

saat guru memberikan pertanyaan seperti "bagaimana detik-detik proklamasi?", siswa memberikan jawaban yang variatif. Ada yang menjawab kejadian proklamasi pada tanggal 17 Agustus 1945, hingga ada yang menjelaskan kronologisnya secara sistematis dari tanggal 16 
Agustus 1945, saat Ir. Soekarno, M. Hatta, dan tokoh lain berkumpul di rumah Laksamana Maeda.

Tidak hanya saat proses pembelajaran, kemampuan berpikir kritis juga terukur saat hasil belajar. Untuk mengukur kemampuan berpikir kritis siswa pada mata pelajaran IPS, instrumen

kelas kontrol disajika $\mathrm{n}$ dalam diagram berikut ini.

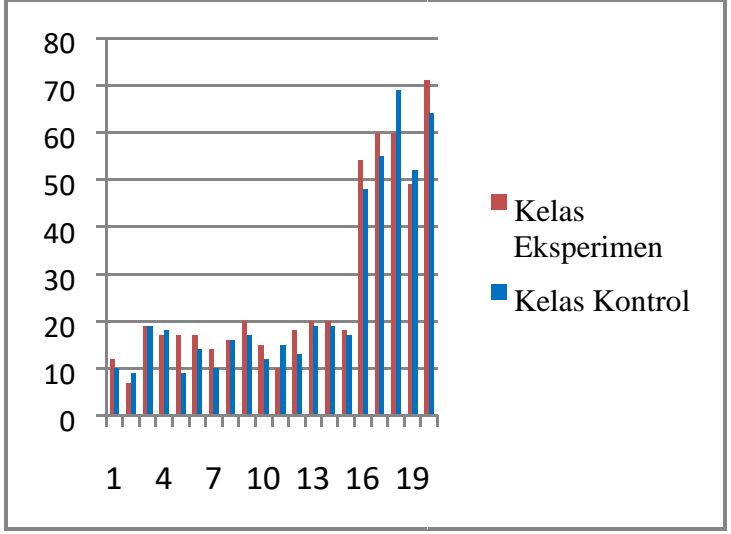

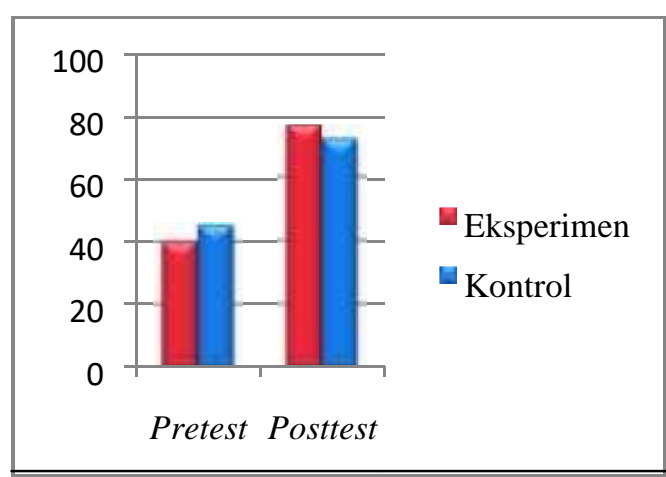

\section{Gambar 2}

Perbandingan Pretest-Posttest Kelas Eksperimen dan Kontrol

tes yang dikembangkan harus mengacu pada indikator berpikir kritis. Dalam penelitian ini, peneliti mengadopsi indikator berpikir kritis menurut Ennis (dalam Nio dkk, 2017, hlm. 58), yang diklasifikasikan menjadi "basic clarification, the bases for the decision, inference, advanced clarification, supposition and integration".

Berdasarkan hasil analisis soal posttest yang dilakukan, mayoritas siswa yang mendapat model NHT mampu menjawab soal dengan kritis, logis, dan sistematis. Berbeda dengan siswa yang mendapat model konvensional berbasis media gambar, yang mampu memberikan jawaban tepat, namun kajian yang kurang mendalam. Misal pada soal uraian nomor 3, "bagaimana tindakan kamu

saat melihat temanmu bermalasmalasan dalam belajar karena menganggap negara ini sudah merdeka?". Siswa di kelas eksperimen menjawab "saya akan menyuruhnya

belajar. Meskipun Indonesia sudah merdeka, tetapi kita harus tetap belajar agar bangsa ini terbentuk menjadi lebih cerdas". Sementara itu, siswa di kelas kontrol menjawab "menyuruh dia belajar".

Adapun rincian hasil jawaban posttest siswa kelas eksperimen dan

\section{Gambar 1}

\section{Rincian Hasil Posttest}

Berdasarkan gambar 1, siswa di kelas eksperimen mampu menjawab soal-soal yang berorientasi pada kemampuan berpikir kritis, dengan baik. Hal ini mengindikasikan bahwa kemampuan berpikir kritis siswa yang mendapat model $N H T$ terbilang tinggi. 3. Pengaruh Model NHT terhadap Kemampuan Berpikir Kritis

Hasil uji hipotesis menggunakan uji t, diperoleh thitung > ttabel. Jika thitung lebih besar dibandingkan dengan $\mathrm{t}_{\text {tabel }}$, maka Ho ditolak dan Ha diterima. Dengan kata lain, terdapat pengaruh model pembelajaran kooperatif tipe $N H T$ terhadap kemampuan berpikir kritis siswa kelas V SDN Tanjungsari pada mata pelajaran IPS. 
Ditolaknya hipotesis nol dan diterimanya hipotesis alternatif, merepresentasikan bahwa siswa kelas eksperimen sudah mendapat perlakuan model $N H T$, sehingga terdapat pengaruh pada kemampuan berpikir kritisnya.

Seperti yang telah dikemukakan, bahwa hasil posttest kedua kelas menunjukkan progres yang lebih baik. Adapun rekapitulasi hasilnya divisualisasikan dalam gambar 2.

Saat pembelajaran berlangsung pada kelas eksperimen, siswa lebih aktif dan responsif dalam mengikuti kegiatan pembelajaran. Hal ini selaras dengan hasil penelitian yang dilakukan oleh Kawuwung (2014) , bahwa model pembelajaran NHT dapat meningkatkan kemampuan berpikir tingkat tinggi, meningkatkan aktivitas siswa dalam pembelajaran, hingga siswa menjadi lebih berani mengemukakan pendapat.

Bagaimana model pembelajaran NHT dapat memengaruhi kemampuan berpikir kritis? Sebagaimana disampaikan Tileston (2007) bahwa NHT merupakan salah satu model pembelajaran aktif. Pembelajaran menggunakan NHT menjadikan semua siswa terlibat aktif, mulai dari mengidentifikasi, menganalisis dan mengevaluasi masalah, yang juga merupakan proses tingkat berpikir kritis. Oleh sebab itu, NHT dapat dengan mudah mendukung proses berpikir kritis. Saat persoalan diberikan, siswa melakukan identifikasi masalah, memberikan hipotesis, kemudian menganalisis dan mendiskusikan masalah tersebut dalam kelompok. Hal ini membuat siswa mampu memberikan evaluasi kritis terhadap permasalahan.

Model NHT sangat efektif untuk melatih siswa menjadi seseorang yang kritis. Pada tahap heads together, siswa terlebih dahulu diberi kesempatan untuk berpikir secara individu sebelum berpikir bersama dalam hal memecahkan masalah, mengambil keputusan, dan menganalisis terkait permasalahan yang diberikan guru. Ketika siswa telah berpikir secara individu, kemudian pada tahapan berpikir bersama, siswa akan dihadapkan dengan pemikiran teman diskusinya yang variatif, maka secara tidak langsung mereka dituntut untuk menyeleksi pemikiran yang paling benar. Dalam menyeleksi ini, siswa berusaha mengevaluasi secara sistematis bobot pendapat, sehingga kondisi semacam ini otomatis dapat membangun karakter pemikiran kritis dalam diri siswa.

Berdasarkan pemaparan tersebut, maka dapat ditarik konklusi bahwa terdapat pengaruh model NHT terhadap kemampuan berpikir kritis siswa kelas V SDN Tanjungsari pada mata pelajaran IPS.

\section{KESIMPULAN}

Penerapan model pembelajaran kooperatif tipe NHT pada siswa kelas V SDN Tanjungsari dalam mata pelajaran IPS terlaksana dengan baik. Kemampuan berpikir kritis siswa yang mendapat model $N H T$ terbilang tinggi.Terdapat pengaruh model pembelajaran kooperatif tipe NHT terhadap kemampuan berpikir kritis siswa kelas V SDN Tanjungsari pada mata pelajaran IPS.

Model NHT membuat siswa menjadi lebih aktif dalam pembelajaran, sehingga kemampuan berpikir kritisnya cenderung terasah. Hal ini dikarenakan siswa dituntut untuk mengungkapkan pendapatnya pada tahap questioning, head together, dan answering. Hasil penelitian digunakan sebagai masukan bagi guru agar mampu melakukan pemilihan model pembelajaran untuk meningkatkan kemampuan berpikir kritis siswa. 


\section{DAFTAR PUSTAKA}

[1] Afriyanti, I. (2012). Penggunaan Media Gambar untuk Meningkatkan Aktivitas dan Hasil Belajar Siswa. (Skripsi). Universitas Tanjungpura,Pontianak.

[2] Arikunto, S. (2012). Prosedur Penelitian. Jakarta: PT Rineka Cipta.

[3] Hamdani. (2011). Strategi Belajar Mengajar. Bandung: CV Pustaka Setia.

[4] Huda, M. (2013). Model-model Pengajaran dan Pembelajaran. Yogyakarta: Pustaka Belajar.

[5] Indira, T., dkk. (2017). Kemampuan Berpikir Kritis Siswa SMP Melalui Pendekatan Pendidikan Matematika Realistik Indonesia. Histogram: Jurnal Pendidikan Matematika. 1 (2), hlm. 61-75.

[6] Johnson, E. (2010). Contextual Teaching and Learning: Menjadikan Kegiatan Belajar Mengajar Mengasyikkan dan Bermakna. Bandung: Kaifa.

[7] Kawuwung, F. R. (2014). Pengaruh Pembelajaran NHT terhadap Kemampuan Berpikir Kritis Biologi Peserta Didik SMA Negeri 1 Wori di Kabupaten Minahasa Utara. Jurnal Pendidikan Biologi, 6, hlm.10-21.

[8] Margono. (2004). Metodologi Penelitian Pendidikan. Jakarta: Rineka Cipta

[9] Menteri Pendidikan Nasional. (2006). Peraturan Menteri Pendidikan Nasional Nomor 22 Tahun 2006 Tentang Standar Isi untuk Satuan Pendidikan Dasar dan Menengah. Jakarta: Mendiknas.

[10] Mulyana, T. (2008). Pembelajaran Analitik Sintetik untuk Meningkatkan Kemampuan Berpikir Kritis dan Kreatif Matematik $\quad$ Siswa SMA. $\quad$ (Disertasi). $\quad$ Sekolah Pascasarjana, Universitas Pendidikan Indonesia, Bandung.

[11] Nio, dkk. (2017). Study on Critical Thinking Skills Basic Prospective Student Primary School Teacher. International Journal of Contemporary Applied Sciences, 4 (1), hlm. 54-70.

[12] Nizar, Said, I., \& Suherman. (2016). Studi Perbandingan Model Pembelajaran Jigsaw dan NHT terhadap Hasil Belajar Stoikiometri Siswa Kelas X SMAN 8 Palu. Jurnal AkademikaKimia. 5, hlm. 133-139

[13] Novita, F. (2018, 16 Desember). PISA dan Literasi Indonesia. [Online]. Diakses dari https://www.kompasiana.com/frnc scnvt/5c1542ec677ffb3b533d610 5/pisa-danliterasi-indonesia.

[14] Sapriya. (2017). Pendidikan IPS (Konsep dan Pembelajaran). Bandung: PT Remaja Rosdakarya.

[15] Solihah, S. (2019). Meningkatkan Kemampuan Berpikir Kritis Matematik Siswa MTs dengan Menggunakan Metode BrainBased Learning. Jurnal Teorema: Teori dan Riset Matematika, 4 (1) , hlm. 55-64

[16] Sugiyono. (2018). Metode Penelitian Kuantitatif, Kualitatif, dan R\&D. Bandung: Alfabeta.

[17] Suparmi. (2012). Pembelajaran Kooperatif dalam Pendidikan Multikultural. Jurnal Pembangunan Pendidikan Fondasi dan Aplikasi, 1 (1), hlm. 108-118.

[18] Susanto, A. (2014). Pengembangan Pembelajaran IPS di Sekolah Dasar. Jakarta: Prenamedia Group.

[19] Tetep \& Suparman, A. (2019). Students' Digital Media Literacy: Effects on Social Character. International Journal of Recent Technology and Engineering (IJRTE). ISSN: $\quad 2277-3878, \quad$ Volume-8 Issue-2S9, September 2019. DOI:10.35940/ijrte.B1091.0982S919.

[20] Tileston, D. W. (2007). Teaching Strategies for Active Learning: Five Essentials for Your Teaching Plan. California: Corwin Press, A Sage Publications Company. 
[21] Ulya, dkk. (2017). Penerapan Model NHT untuk Meningkatkan Hasil Belajar Siswa pada Mata Pelajaran IPS Kelas V. Jurnal Pena Ilmiah, 2 (1), hlm. 20612070.

[22] Yuswanti, A. (2018). Penggunaan Media Gambar untuk Meningkatkan Hasil Belajar Siswa pada Pembelajaran IPS di Kelas IV SD PT Lestari Tani Teladan Kabupaten Donggola. Jurnal Kreatif Tadulako Online, 3(4), hlm. 185-199. 